\title{
UTILIZATION OF THE TREATMENT PLANT'S SLUDGE AS A GLASS
}

\author{
Mehmet Burçin Piskin \\ Nurcan Tugrul \\ Emek Moroydor Derun \\ Ihsan Mert Türkkal \\ Ylldiz Technical University
}

\begin{abstract}
In this study, physical and chemical characteristic of the treatment sludge obtained by Bergama- Ovacik treatment plant and the possibility to evaluate them in glass industry were investigated. In this treatment plant, 277,882 tons of sludge is annually produced. The chemical composition of the waste sludge's is determined by gravimetric method and it is examined by X-Ray diffraction (XRD), X-Ray fluorescence (XRF) and Fourier Transform Infrared Spectrophotometer (FT-IR) equipments. The chemical composition of the treatment sludge showed that it is potential to be used in a glass industry to produce Borosilicate glass and Flat glass with the addition of chemical substances. In order to examine the composition of the samples, their analyses were made by (FT-IR) and (XRF) equipments.
\end{abstract}

\section{KEYWORDS}

Treatment sludge; Flat glass; Borosilicate glass.

\section{INTRODUCTION}

Recycling and evaluation of wastes obtained from the industrial processes has become a worldwide concern, especially in the last few years and claims for a solution in the near future [1].

Domestic and Industrial wastewater treatment with physical, chemical and biological processes have approximately between $0.25-12 \%$ of solid substances, being known as sludge. [2].

This sludge leads to some serious environmental problems because of the presence of pathogen and toxic compounds. Besides, it constitutes significant storage and transport problems. In the treatment plants, the units which are related to the disposal of the sludge that comes out constitute approximately $50 \%$ of the total investment cost [3]. Due to the development of industry and the increasing population in Turkey, the studies and researches about this topic are being considered to be significant especially in the last years.

It is clear that the sludge from wastewater treatment plants will reach larger amounts because of the increasing population and the addition of the new treatment plants. On account of the problems of the treatment sludge will reach wider extents in the forthcoming years. For instance; in Turkey approximately 3 million tons of sludge is produced from the industrial wastewater treatment plants in a year [4]. However, these wastes will be decreased in a 
distinctive rate by the evaluation with a proper process and it can be beneficial in both economic and environmental aspects, by the use of raw materials or fuel especially in energy production.

Vitrification is a well-established technique for converting several wastes into materials for possessing is considered to be a remarkable chemical stability. In fact, various inorganic wastes are constituted by glass-forming oxides or may be dissolved in a silicate melt provided by glass-forming additives [5].

In this study, the determination of the characteristics of the sludge obtained by BergamaOvacik Gold Mine treatment plant and the use as raw materials in Glass Industry have been investigated.

\section{EXPERIMENTAL}

\subsection{Material}

The treatment of sludge that is assured by Bergama-Ovacık Gold Management Plant was used as a basic raw material in experimental studies. During the production, 277,882 tons of treatment sludge is erupted in the treatment plant every year. The sludge contains $89.42 \%$ of $\mathrm{SiO}_{2}$. The chemical composition of the sludge is given in Table 1. Moreover, in order to produce glass, sodium carbonate, boric acid, calcium carbonate and magnesium carbonate were used as chemical additives.

Table 1. Chemical composition of Bergama waste.

\begin{tabular}{ccccccc}
\hline $\mathrm{SiO}_{2}(\%)$ & $\mathrm{AI}_{2} \mathrm{O}_{3}(\%)$ & $\mathrm{Fe}_{2} \mathrm{O}_{3}(\%)$ & $\mathrm{CaO}(\%)$ & $\mathrm{Na}_{2} \mathrm{O}(\%)$ & $\mathrm{K}_{2} \mathrm{O}(\%)$ & Total $(\%)$ \\
\hline 89.42 & 3.85 & 2.12 & 0.30 & 0.1 & 1.69 & 100 \\
\hline
\end{tabular}

\subsection{Equipment}

- High temperature furnace, which can reach to $1600^{\circ} \mathrm{C}$ in order to melt glass and melting pots which are durable to high temperature were used.

- Chemical characterization of the waste and the obtained glasses were carried out using Spektro X-LabPro X-ray fluorescence (XRF) apparatus. 


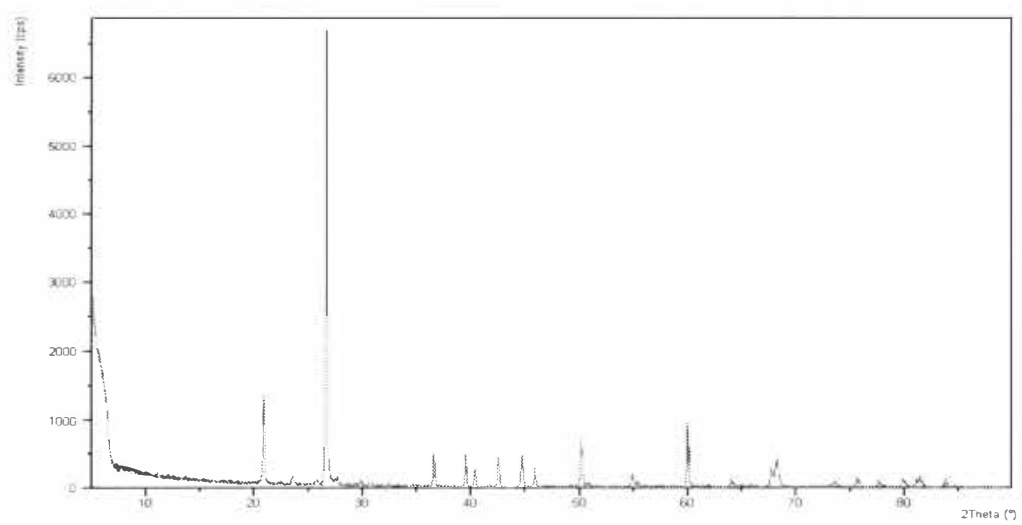

Figure 1. XRD diagram of the waste.

- Perkin Elmer Fourier Transform Infrared Spectrophotometer (FT-IR) was used for investigation of chemical bounds and molecular structure of materials. Experiments were carried out in the variation of wavelengths from 4000 to $450 \mathrm{~cm}^{-1}$. Powdered samples were mixed with $\mathrm{KBr}$ and sample pellets were obtained after applying pressure of 100 bar.

- The X-ray diffraction (XRD) measurements of the obtained waste were carried out using a Philips Panalytical X'Pert Pro diffractometer, with a $\mathrm{Cu}-\mathrm{K} \alpha$ source, at $45 \mathrm{kV}$ and $40 \mathrm{~mA}$. The samples were mounted on a glass sample holder.

\section{RESULTS}

\subsection{Characterization of the waste}

The functional group and micro structural characteristics of the waste were examined by XRD, XRF and FT-IR instrumental analysis device.

\subsubsection{XRD diagram of the waste}

The XRD diagram was recorded to be diffraction angle which changes between $0-90$. According to the XRD diagram, that is given Figure 1, the characteristic peaks of the waste were seemed to be in approximately $208,27 \AA$, and 608 diffraction angle.

\subsubsection{FT-IR spectrum of the waste}

The functional group structure of the samples between $4000-650 \mathrm{~cm}^{-}{ }^{1}$ wavelengths, were examined by FT-IR spectrometric method. The sample made to become a pellet by mixing $\mathrm{KBr}$ powder at a proper rate and it is prepared for FT-IR analysis. FT-IR absorption band obtained for waste sludge were centered at $2184,1039,795,777,693 \mathrm{~cm}^{-1}$. The band at 2184 $\mathrm{cm}^{-1}$ shows the absorption bands of the $\mathrm{O}-\mathrm{H}$ stretching. It can be seen from Figure 2 that there is a broad band centered at vibration at $1039 \mathrm{~cm}^{-1}[6]$. The band can be attributed to Si-O-Si symmetric stretching in cyclic structure. There is a band centered at $795 \mathrm{~cm}^{-1}$ and a sharp vibration at $777 \mathrm{~cm}^{-1}$. Two bands were attributed to the $\mathrm{SiO}_{4}$ asymmetric $\mathrm{Si}-\mathrm{O}-\mathrm{Si}$ band $\left(\mathrm{SiO}_{2}\right)$. The band at $693 \mathrm{~cm}^{-1}$ was assigned to the $\mathrm{O}-\mathrm{Si}-\mathrm{O}$ band [7]. 


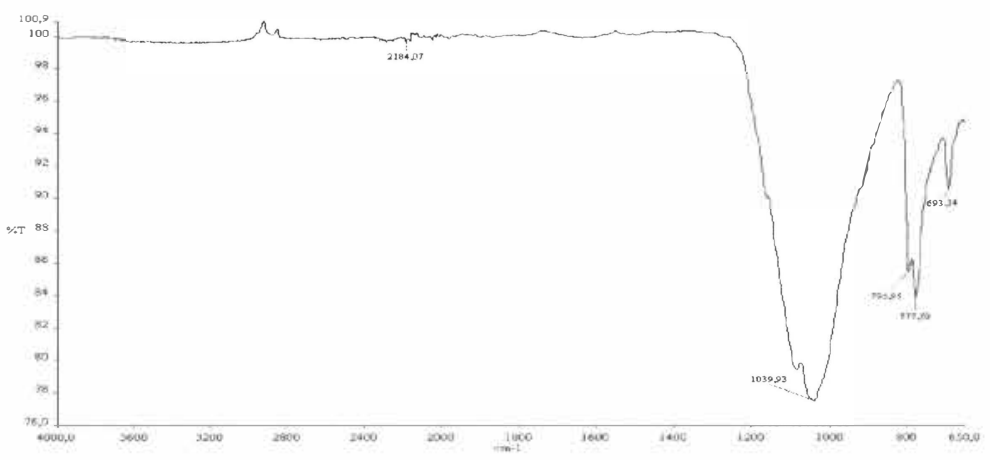

Figure 2. FT-IR spectrum of the waste.

\subsubsection{XRF results of the waste}

The chemical composition of the waste was examined by X-Ray fluorescence technique. When the XRF results of the sludge were examined, it was observed that the waste has Fe ion in large amounts (Table 2).

Table 2. XRF results of the waste.

\begin{tabular}{cccc}
\hline Element & Concentration & Element & Concentration \\
\hline $\mathrm{Ti}$ & $<0.0069$ & $\mathrm{In}$ & $<0.030$ \\
\hline $\mathrm{V}$ & $<0.0269$ & $\mathrm{Sn}$ & $<0.050$ \\
\hline $\mathrm{Cr}$ & $<0.030$ & $\mathrm{Sb}$ & $<0.050$ \\
\hline $\mathrm{Mn}$ & 0.0312 & $\mathrm{~W}$ & $<0.025$ \\
\hline $\mathrm{Fe}$ & 1.48 & $\mathrm{Ga}$ & $<0.010$ \\
\hline $\mathrm{Co}$ & $<0.020$ & $\mathrm{Zr}$ & 0.050 \\
\hline $\mathrm{Ni}$ & $<0.015$ & $\mathrm{Nb}$ & 0.1402 \\
\hline $\mathrm{Cu}$ & $<0.010$ & $\mathrm{Au}$ & $<0.020$ \\
\hline $\mathrm{Mo}$ & 0.2527 & $\mathrm{~Pb}$ & $<0.020$ \\
\hline $\mathrm{Pd}$ & 0.02360 & $\mathrm{Rh}$ & $<0.002$ \\
\hline $\mathrm{Ag}$ & 0.002 & $\mathrm{Zn}$ & 0.0100 \\
\hline $\mathrm{Cd}$ & $<0.050$ & $\mathrm{Pt}$ & $<0.020$ \\
\hline
\end{tabular}

\subsection{Glass production}

\subsubsection{Borosilicate glass production}

Three frits were prepared for Borosilicate Glass production, and they were called BG-1, BG2, and BG-3 glasses (see Table 3). Three mixtures were prepared by adding boric acid and sodium carbonate to the treatment sludge obtained from Bergama for Borosilicate Glass (Pyrex) production. The chemical compositions of these mixtures were given in the Table 4. 
Table 3. The mixtures that were prepared for Borosilicate glasses.

\begin{tabular}{cccc}
\hline Glass identity & $\mathrm{BG}-1$ & $\mathrm{BG}-2$ & $\mathrm{BG}-3$ \\
\hline Waste Loadinge $\%)$ & 83 & 85 & 80 \\
\hline $\mathrm{SiO}_{2}(\%)$ & - & - & - \\
\hline $\mathrm{B}_{2} \mathrm{O}_{3}(\%)$ & 13 & 12 & - \\
\hline $\left.\mathrm{Al}_{2} \mathrm{O}_{3} \mathrm{Q} \%\right)$ & - & - & - \\
\hline $\mathrm{MgO}(\%)$ & - & - & - \\
\hline $\mathrm{CaO}(\%)$ & - & - & 5 \\
\hline $\mathrm{Na}_{2} \mathrm{O}(\%)$ & 4 & 3 & - \\
\hline $\mathrm{K}_{2} \mathrm{O}(\%)$ & - & - & 1325 \\
\hline $\mathrm{Total} \%)$ & 100 & 100 & \\
\hline Melting Temperatures $(\mathrm{eC})$ & 1350 & 1350 & \\
\hline
\end{tabular}

Table 4. Chemical composition of the samples after the mixture in Borosilicate glasses production.

\begin{tabular}{ccccccccc}
\hline Glass identity & $\begin{array}{c}\mathrm{SiO}_{2} \\
(\%)\end{array}$ & $\begin{array}{c}\mathrm{B}_{2} \mathrm{O}_{3} \\
(\%)\end{array}$ & $\begin{array}{c}\mathrm{Al}_{2} \mathrm{O}_{3} \\
(\%)\end{array}$ & $\begin{array}{c}\mathrm{Fe}_{2} \mathrm{O}_{3} \\
(\%)\end{array}$ & $\begin{array}{c}\mathrm{CaO} \\
(\%)\end{array}$ & $\begin{array}{c}\mathrm{Na}_{2} \mathrm{O} \\
(\%)\end{array}$ & $\begin{array}{c}\mathrm{K}_{2} \mathrm{O} \\
(\%)\end{array}$ & $\begin{array}{c}\text { Total } \\
(\%)\end{array}$ \\
\hline BG-1 & 75.2 & 11.9 & 3.2 & 1.78 & 0.25 & 4.2 & 1.42 & 100 \\
\hline BG-2 & 76 & 12 & 3.27 & 1.8 & 0.225 & 3 & 1.437 & 100 \\
\hline BG-3 & 71.5 & 15 & 3.08 & 1.7 & 0.24 & 5 & 1.35 & 100 \\
\hline
\end{tabular}

The mixtures were mixed in a grinder for two hours. The mixtures which are prepared for Borosilicate Glass Production were put into the melting pot and they were melted in high temperature furnace. The $\mathrm{BG}-1$ glass was melted at $1350 \mathrm{eC}, \mathrm{BG}-2$ glass was melted at $1350 \AA \mathrm{C}$ and the last glass $\mathrm{BG}-3$ was melted at $1325^{\circ} \mathrm{C}$ by controlling during definite time periods. The aspects of the melted glasses after cooling are shown in Figure $3 a-c$.

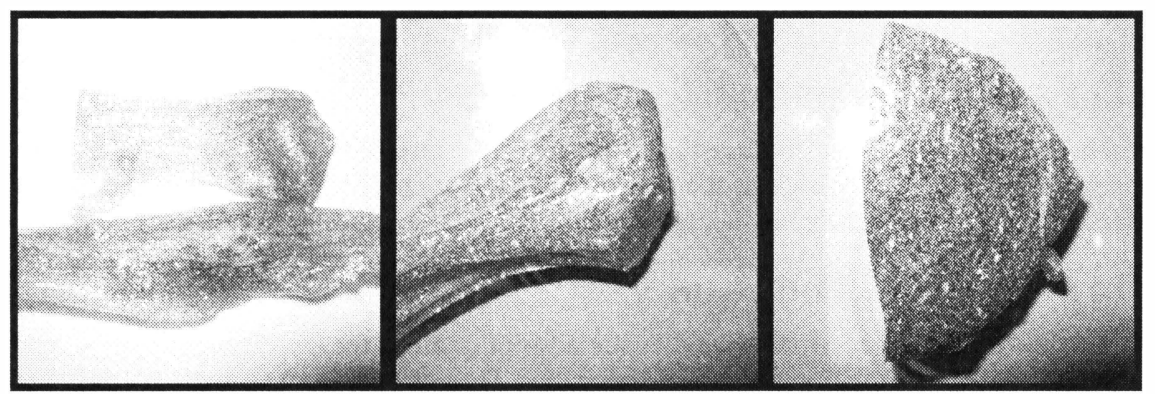

(a) (b) (c)

Figure 3. Aspect of the: (a) $B G-1$, (b) $B G-2$ and (c)BG-3 glasses at room temperature 
Kalmar ECO-TECH 07

KALMAR, SWEDEN, November 26-28, 2007

Table 5. XRF results of $B G-1, B G-2$ and $B G-3$ glasses.

\begin{tabular}{|c|c|c|c|}
\hline & $\begin{array}{c}\text { XRF results of } \\
\text { BG- } 1\end{array}$ & $\begin{array}{c}\text { XRF results of } \\
\text { BG-2 }\end{array}$ & $\begin{array}{c}\text { XRF results of } \\
\text { BG-3 }\end{array}$ \\
\hline Element & Concentration & Concentration & Concentration \\
\hline $\mathrm{Ti}$ & $<0.0077$ & $<0.0068$ & $<0.0074$ \\
\hline $\mathrm{V}$ & 0.0172 & $<0.035$ & 0.0152 \\
\hline $\mathrm{Cr}$ & $<0.030$ & $<0.030$ & $<0.030$ \\
\hline $\mathrm{Mn}$ & 0.0352 & 0.0242 & 0.0326 \\
\hline $\mathrm{Fe}$ & 2.246 & 1.26 & 2.19 \\
\hline Co & $<0.020$ & $<0.020$ & $<0.020$ \\
\hline $\mathrm{Ni}_{1}$ & $<0.015$ & $<0.015$ & $<0.015$ \\
\hline $\mathrm{Cu}$ & $<0.010$ & $<0.010$ & $<0.010$ \\
\hline Mo & 0.2687 & 0.2275 & 0.2617 \\
\hline $\mathrm{Pd}$ & 0.02071 & 0.01861 & 0.02071 \\
\hline $\mathrm{Ag}$ & 0.01812 & 0.01850 & 0.01945 \\
\hline Cd & $<0.050$ & $<0.050$ & $<0.050$ \\
\hline In & $<0.030$ & $<0.030$ & $<0.030$ \\
\hline $\mathrm{Sn}$ & $<0.050$ & $<0.050$ & $<0.050$ \\
\hline $\mathrm{Sb}$ & $<0.050$ & $<0.050$ & $<0.050$ \\
\hline W & $<0.025$ & $<0.025$ & $<0.025$ \\
\hline $\mathrm{Ga}$ & $<0.010$ & $<0.010$ & $<0.010$ \\
\hline $\mathrm{Zr}$ & 0.0555 & 0.05017 & 0.05658 \\
\hline $\mathrm{Nb}$ & 01590 & 01125 & 0.1473 \\
\hline $\mathrm{Au}$ & $<0.020$ & $<0.020$ & $<0.020$ \\
\hline $\mathrm{Pb}$ & 0.0256 & 0.01842 & 0.0222 \\
\hline $\mathrm{Rh}$ & $<0002$ & $<0.002$ & $<0.002$ \\
\hline $\mathrm{Zn}$ & $<0.010$ & $<0.010$ & $<0.010$ \\
\hline $\mathrm{Pt}$ & $<0020$ & $<0.020$ & $<0.020$ \\
\hline
\end{tabular}

\subsubsection{Borosilicate glass XRF results}

The chemical compositions of Borosilicate Glass were examined with X-Ray fluorescence technique. When the XRF result of the sample that is given in Table 5 was examined, it was observed that the glass has $\mathrm{Fe}$ ion in large amounts.

\subsubsection{Borosilicate glass FT-IR results}

In our study we made use of the characteristic absorption lines for the crystalline $\mathrm{SiO}_{2}$. The FT-IR spectrums of Borosilicate Glass were shown in Figures 4, 5 and 6. 
Kalmar ECO-TECH '07

KALMAR, SWEDEN, November 26-28, 2007

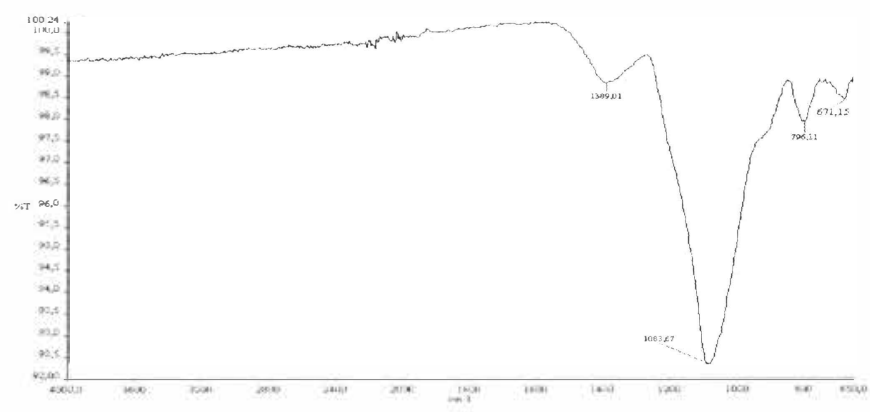

Figure 4. FT-IR spectrum of the BG-1 glass.

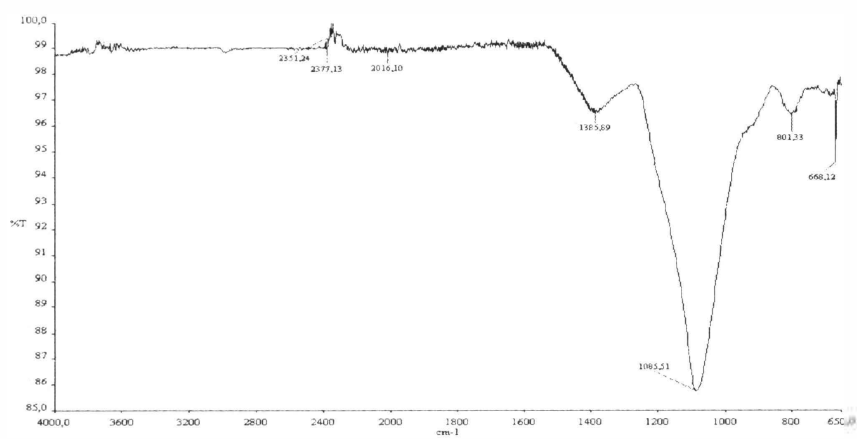

Figure 5. FT-IR spectrum of the BG-2 glass.

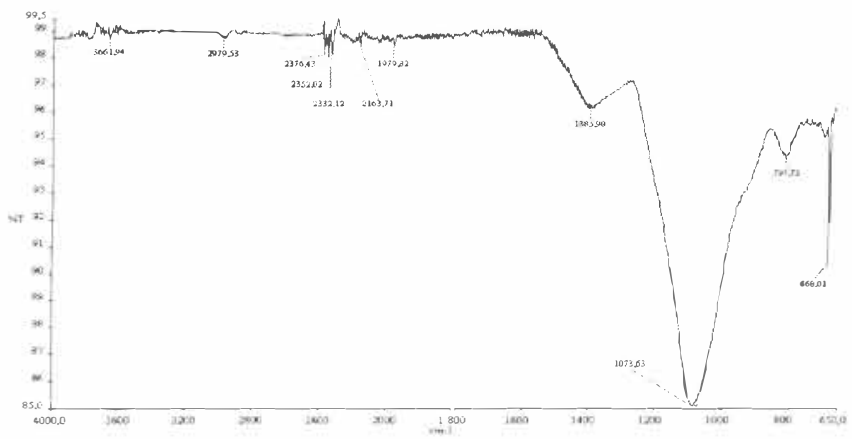

Figure 6. FT-IR spectrum of the BG-3 glass. 


\subsubsection{Flat glass production}

Three frits called FG-1, FG-2 and FG-3 glasses were prepared for Flat Glass production. Mixtures were prepared by adding sodium carbonate; calcium carbonate and magnesium sulfate to the waste sludge obtained from Bergama for the flat glass production (see Table 6). The melting temperatures were determined respectively as $1282 \mathrm{eC}, 1250 \mathrm{e} C$ and $1250 \mathrm{e}$. The aspect of the melted glasses at room temperature was shown in Figure $7 a-c$.

Table 6. The mixtures that were prepared for Flat glasses.

\begin{tabular}{ccccccccc}
\hline Glass identity & $\begin{array}{c}\mathrm{SiO}_{2} \\
(\%)\end{array}$ & $\begin{array}{c}\mathrm{Al}_{2} \mathrm{O}_{3} \\
(\%)\end{array}$ & $\begin{array}{c}\mathrm{Fe}_{2} \mathrm{O}_{3} \\
(\%)\end{array}$ & $\begin{array}{c}\mathrm{MgO} \\
(\%)\end{array}$ & $\begin{array}{c}\mathrm{CaO} \\
(\%)\end{array}$ & $\begin{array}{c}\mathrm{Na}_{2} \mathrm{O} \\
(\%)\end{array}$ & $\begin{array}{c}\mathrm{K}_{2} \mathrm{O} \\
(\%)\end{array}$ & $\begin{array}{c}\text { Total } \\
(\%)\end{array}$ \\
\hline FG-1 & 68.0 & 2.927 & 1.61 & 3.6 & 0.25 & 14.06 & 1.28 & 100 \\
\hline FG-2 & 76.0 & 3.25 & 1.80 & - & 0.255 & 15.085 & 1.436 & 100 \\
\hline FG-3 & 70 & 3 & 1.65 & - & 7 & 15 & 1.31 & 100 \\
\hline
\end{tabular}

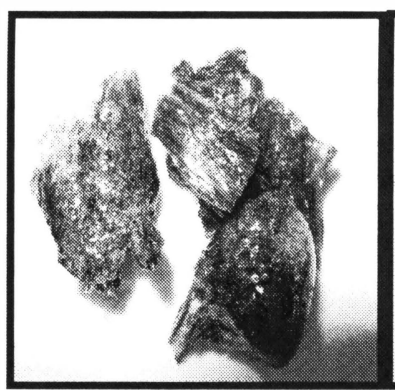

(a)

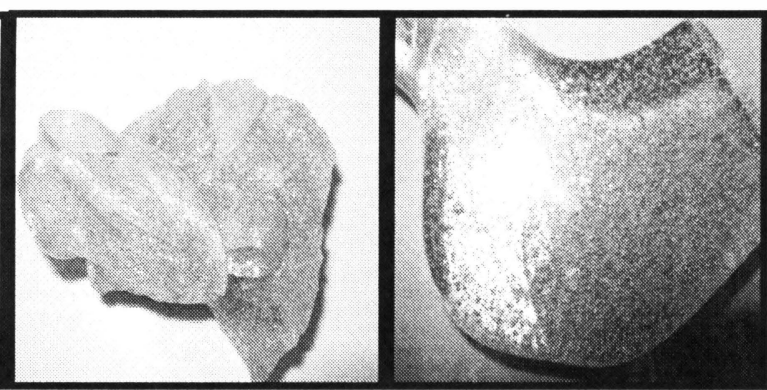

(b)

(c)

Figure 7. ,Aspect of: (a) FG-1, (b) FG-2 and (c) FG-3 glass at room temperature.

\subsubsection{XRF result of flat glass}

The chemical compositions of Flat Glass were examined with X-Ray fluorescence technique and it was observed that the glass has Fe ion in large amounts (see Table 7).

\subsubsection{FT-IR results of flat glass}

The FT-IR spectrums of Flat Glass were shown in Figures 8.9 and 10. 
Table 7. XRF results of FG-1,FG-2 and FG-3 glasses.

\begin{tabular}{c|cc|cc|c}
\hline \multicolumn{2}{c}{ XRF results of FG-1 } & \multicolumn{2}{c}{ XRF results of FG-2 } & \multicolumn{2}{c}{ XRF results of FG-3 } \\
\hline Element & Concentration & Element & Concentration & Element & Concentration \\
\hline $\mathrm{Ti}$ & $<0.0073$ & $\mathrm{Ti}$ & $<0.0067$ & $\mathrm{Ti}$ & $<0.0052$ \\
\hline $\mathrm{V}$ & 0.0173 & $\mathrm{~V}$ & $<0.035$ & $\mathrm{~V}$ & $<0.035$ \\
\hline $\mathrm{Cr}$ & $<0.030$ & $\mathrm{Cr}$ & $<0.030$ & $\mathrm{Cr}$ & $<0.030$ \\
\hline $\mathrm{Mn}$ & 0.0289 & $\mathrm{Mn}$ & $<0.025$ & $\mathrm{Mn}$ & $<0.025$ \\
\hline $\mathrm{Fe}$ & 1.127 & $\mathrm{Fe}$ & 1.26 & $\mathrm{Fe}$ & 1.155 \\
\hline $\mathrm{Co}$ & $<0.020$ & $\mathrm{Co}$ & $<0.020$ & $\mathrm{Co}$ & $<0.020$ \\
\hline $\mathrm{Ni}$ & $<0.015$ & $\mathrm{Ni}$ & $<0.015$ & $\mathrm{Ni}$ & $<0.015$ \\
\hline $\mathrm{Cu}$ & $<0.010$ & $\mathrm{Cu}$ & $<0.010$ & $\mathrm{Cu}$ & $<0.010$ \\
\hline $\mathrm{Mo}$ & 0.2507 & $\mathrm{Mo}$ & 0.1748 & $\mathrm{Mo}$ & 0.1692 \\
\hline $\mathrm{Pd}$ & 0.01993 & $\mathrm{Pd}$ & $<0.020$ & $\mathrm{Pd}$ & $<0.020$ \\
\hline $\mathrm{Ag}$ & 0.01898 & $\mathrm{Ag}$ & $<0.020$ & $\mathrm{Ag}$ & $<0.020$ \\
\hline $\mathrm{Cd}$ & $<0.050$ & $\mathrm{Cd}$ & $<0.050$ & $\mathrm{Cd}$ & $<0.050$ \\
\hline $\mathrm{In}$ & $<0.030$ & $\mathrm{In}$ & $<0.030$ & $\mathrm{In}$ & $<0.030$ \\
\hline $\mathrm{Sn}$ & $<0.050$ & $\mathrm{Sn}$ & $<0.050$ & $\mathrm{Sn}$ & $<0.050$ \\
\hline $\mathrm{Sb}$ & $<0.050$ & $\mathrm{Sb}$ & $<0.050$ & $\mathrm{Sb}$ & $<0.050$ \\
\hline $\mathrm{W}$ & $<0.025$ & $\mathrm{~W}$ & $<0.025$ & $\mathrm{~W}$ & $<0.025$ \\
\hline $\mathrm{Ga}$ & $<0.010$ & $\mathrm{Ga}$ & $<0.010$ & $\mathrm{Ga}$ & $<0.010$ \\
\hline $\mathrm{Zr}$ & 0.05116 & $\mathrm{Zr}$ & 0.1643 & $\mathrm{Zr}$ & $<0.050$ \\
\hline $\mathrm{Nb}$ & 0.1265 & $\mathrm{Nb}$ & $<0.020$ & $\mathrm{Nb}$ & 0.09989 \\
\hline $\mathrm{Au}$ & $<0.020$ & $\mathrm{Au}$ & $<0.020$ & $\mathrm{Au}$ & $<0.020$ \\
\hline $\mathrm{Pb}$ & 002443 & $\mathrm{~Pb}$ & 0.0256 & $\mathrm{~Pb}$ & 0.020 \\
\hline $\mathrm{Rh}$ & $<0.002$ & $\mathrm{Rh}$ & $<0.002$ & $\mathrm{Rh}$ & $<0.002$ \\
\hline $\mathrm{Zn}$ & $<0.010$ & $\mathrm{Zn}$ & $<0.010$ & $\mathrm{Zn}$ & $<0.010$ \\
\hline $\mathrm{Pt}$ & $<0.020$ & $\mathrm{Pt}$ & $<0.020$ & $\mathrm{Pt}$ & $<0.020$ \\
\hline & & & &
\end{tabular}

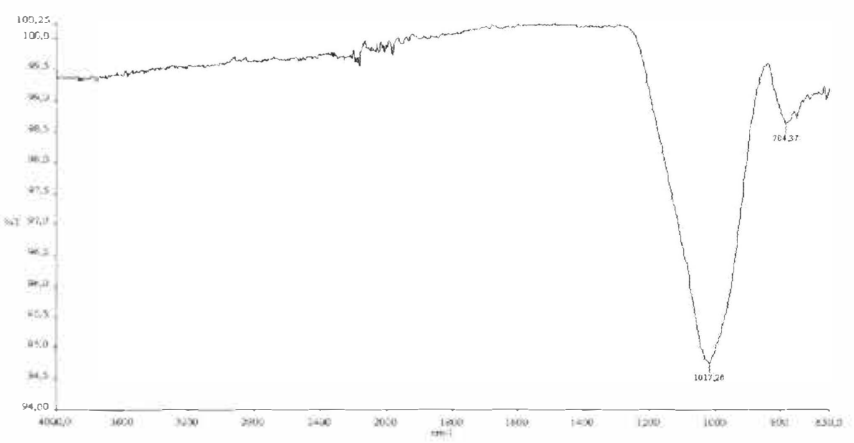

Figure 8. FT-IR spectrum of the FG-I glass. 


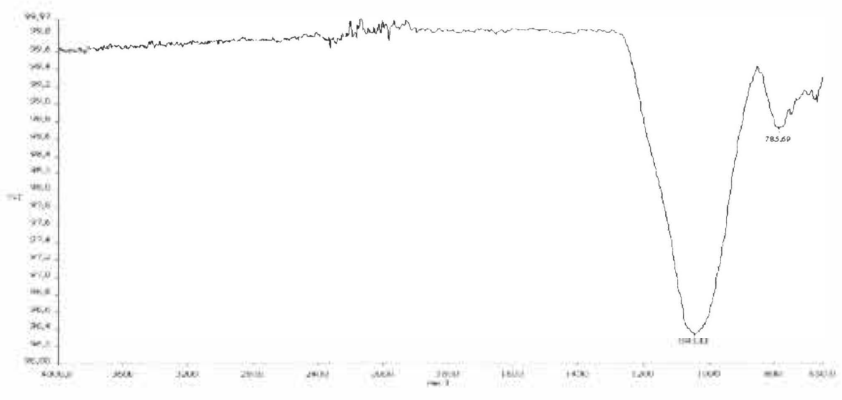

Figure 9. FT-IR spectrum of the FG-2 glass.

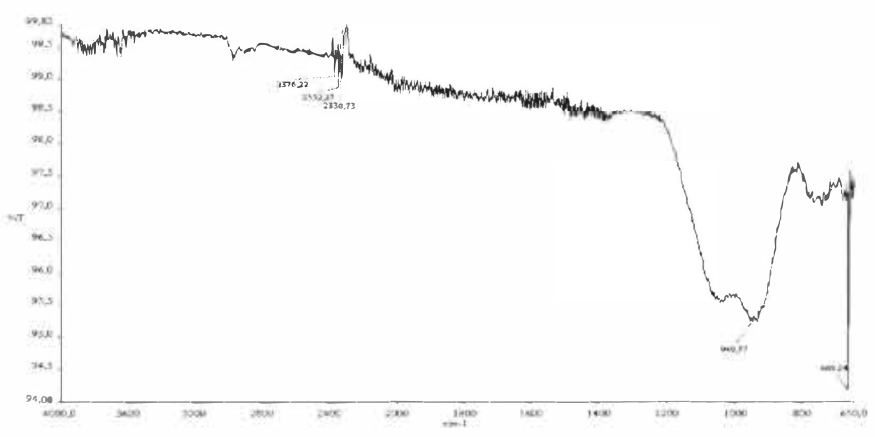

Figure 10. FT-IR spectrum of the FG-3 glass.

\section{CONCLUSIONS}

The waste contains $89.42 \% \mathrm{SiO}_{2}$, and this is a proof that the waste can be used in the glass industry. Two different samples and two types of glass were obtained by adding different kinds of additives. There were remarkable color differences in the samples. These differences were occurred by $2.12 \%$ of $\mathrm{Fe}_{2} \mathrm{O}_{3}$ which exists in the waste. The iron causes BG-1 glass to be light green-grey, BG-2 glass to be green-grey, BG-3 glass to be dark green-grey and also FG1 glass sample to be dark green, FG-2 glass to be green, FG-3 glass to be light green. The melting was completed in Borosilicate glass at an average of $1350-1325^{\circ} \mathrm{C}$, in Flat glass sample at average $1282-1250{ }^{\circ} \mathrm{C}$. The purpose of this study is the disposal of the treatment sludge and the usage of the glasses for a decorative purpose; we can provide the disposal of glasses. In conclusion, 277,882 tons of sludge was generated as a waste sludge in BergamaOvacık Gold Mine every year. From this result, the firm will not have the disposal cost of the waste, which is used as raw material; it will form a new source of income. The vital point of the waste is not only just the specific section of the waste but also the whole waste was used as the raw material. 


\section{REFERENCES}

[1] Silva, A.C., Mello Castanho, S.R.H., 2004. Silicate glasses obtained from fine silica powder modified with galvanic waste addition. Journal of Non-Crystalline Solids 348, 211-217.

[2] Orhon, D., 1991. Ön Antmanın Projelendirilmesi ve Endüstriyel Atıkların Ön Arıtılması, Teknoloji İletimi Semineri vol.1, ISO-SKATMK., 131-173.

[3] Winkler, M., 2000. Waste Treatment and Disposal, John Wiley and Sons Ltd, England, 417.

[4] DİE, İmalat Sanayi Atik Envanteri Anket Sonuçlari, DİE Yayini, 1994.

[5] Bernardo, E., Varrasso, M., Cadamuro, F., Hreglich, S., 2006. Vitrification of wastes and preparation of chemically stable sintered glass-ceramic products. Journal of NonCrystalline Solids 352, 4017-4023.

[6] Rubio, F., Rubio, J., Oteo, J.L., 1998. A FT-IR Study of the Hydrolysis of Tetraethylorthosilicate (TEOS). Spectroscopy Letters 31, 199-219.

[7] Yang, P., Song, C.F., Lü, M.K., Yin, X., Zhou, G.J., Xu, D., Yuan, D.R., 2001. The luminescence of $\mathrm{PbS}$ nanoparticles embedded in sol-gel silica glass. Chemical Physics Letters 345, 429-434. 